\title{
Floristic Composition of Weeds in Opium Poppy Grown Under Climatic Conditions of Malwa Plateau of Madhya Pradesh, India
}

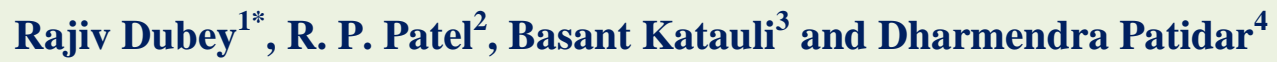 \\ ${ }^{1}$ Department of Agronomy, KNK College of Horticulture, Mandsaur (MP), India \\ ${ }^{2}$ Department of Plant Pathology, KNK College of Horticulture, Mandsaur (MP), India \\ ${ }^{3}$ Department of Plant Breeding \& Genetics, KNK College of Horticulture, \\ Mandsaur (MP), India \\ ${ }^{4}$ Department of Fruit Science, KNK College of Horticulture, Mandsaur (MP), India
}

*Corresponding author

A B S T R A C T

Keywords

Phytosociology, opium poppy

Article Info

Accepted:

20 January 2018

Available Online:

10 February 2018
Study was conducted to assess the phytosociological studies in opium poppy at Mandsaur district of Madhya Pradesh state of India during 201617. A total ten weed species were found and identified. The results obtained indicated that Chenopodium album was most densely populated. The most important weeds that were associated with the opium poppy crop in the study area are of broad-leaved weeds.

\section{Introduction}

The word "opium" is derived from Greek word "opos" (juice) and "opion" (poppy juice). Opium poppy (Papaver somniferum) is a species of flowering plant in the family papaveraceae. It is the species of plant from which opium and poppy seeds are derived. Legal farming of opium takes place in India, Australia and Turkey. Opium poppy contains many alkaloids such as morphine (up to $20 \%$ ), thebaine $(5 \%)$, codeine $(1 \%)$, papaverine $(1 \%)$, and narcotine $(5-8 \%)$ that are naturally present and extracted from poppy and frequently used as an analgesic, anti-tussive and anti spasmodic in modern medicine. In India, opium poppy involves lancing and collection of latex from the incised capsule. The capsule of the plant is the most significant organ as it provides raw opium- a milky exudates. Weed menace in opium is severe due to its slow growing nature. Many broadleaved weeds and some grassy and sedge competed severely with opium especially its early stages of crop growth. The main weeds of opium include Anagalis arvensis, Chenopodium album, Chichorium intybus, Phalaris minor, Melilotus indica and Rumex 
acetolus etc. For effective management of weeds for such situation, basic understanding of the floristic composition of weeds in that particular locality becomes imperative. Survey of weeds is crucial to determine the occurrence and relative importance of weed species in crop production system (Thomas 1985; McCully et al., 1991; Frick and Thomas, 1992 and Korres et al., 2002). Phytosociological study gives an appraisal of plants or weeds of importance in an area with fact and figures; provide overall information on the species-wise distribution in and around crops of a given area and; compare and classify weeds in a crop-weed ecosystem (Zimdahl, 2007, Das, 2008).

\section{Materials and Methods}

Mandsaur district of Madhya Pradesh state is famous for opium production in India. The district area extends between the parallels of latitude 230 46' and 240 45' North and between the meridians of longitude 740 44' and 750 54' East, and it is falling in the Survey of India Topo Sheet No. 45P and 46M. The climate of the Mandsaur district is semitropical characterized by hot summer and well-distributed rainfall during the southwest monsoon. The average annual rainfall of Mandsaur district is $657.3 \mathrm{~mm}$.

A phytosociological survey of weeds flora was undertaken in Bahadari Farm, Kailash Nath Kataju College of Horticulture, Mandsaur (Madhya Pradesh) and villages of Mandsaur district viz., Richha Bachchha, Nogawan, Budha and Karoli during 25 days after sowing (DAS) of crop (before first weeding). This sampling time was chosen because a most of the weeds were well established in this time and most of the annual weeds were only observed before the first weeding. The number and size of sample quadrats used were 10 and $0.25 \mathrm{~m}^{2}$, respectively. The weed samples within each quadrat was removed, washed with tap water and separated by species. The phytosociological attributes were computed using the following principles as presented by Das (2008).

Relative Frequency $(R F)=\frac{\text { Frequency of a species }}{\text { Frequency of all species }} X 100$

Relative Abundance/dominance $(R A)=\frac{\text { Abundance of a species }}{\text { Abundance of all species }} \times 100$

Relative Density $(R D)=\frac{\text { Density of a species }}{\text { Density of all species }} X 100$

Importance value index (IVI) $=R F+\mathrm{RA}+\mathrm{RD}$

\section{Results and Discussion}

The weed flora comprised of two grasses, one sedge and seven broad leaved weeds (Table 1, 2 and Figure 1). The relative abundance, relative density, relative frequency, importance value index, importance value percentage and summed dominance ratio is provided in Table 1.The result of study showed that Chenopodium album predominated the weed flora with a relative abundance of 42.73 per cent, relative density of 66.05 per cent, relative frequency of 22.73 per cent, importance value index (IVI) of 131.51, importance value percentage (IVP) of 43.84 per cent and summed dominance ratio (SDR) of 44.39. The next weed in the order of co-dominance was Cyperus rotundus with relative density of 13.43 per cent, relative frequency of 20.45 per cent, IVI of 43.54 per cent, IVP of 14.51 per cent and SDR of 16.94. Density indicates the numerical strength of a species in a particular community. Abundance gives the number of individuals of a species in a particular habitat. Generally, frequency and abundance are co-related to find out the distribution of a species. Importance Value Index (IVI) is a measure of dominance and ecological success of a species. 
MAP: Madhya Pradesh and Mandsaur District
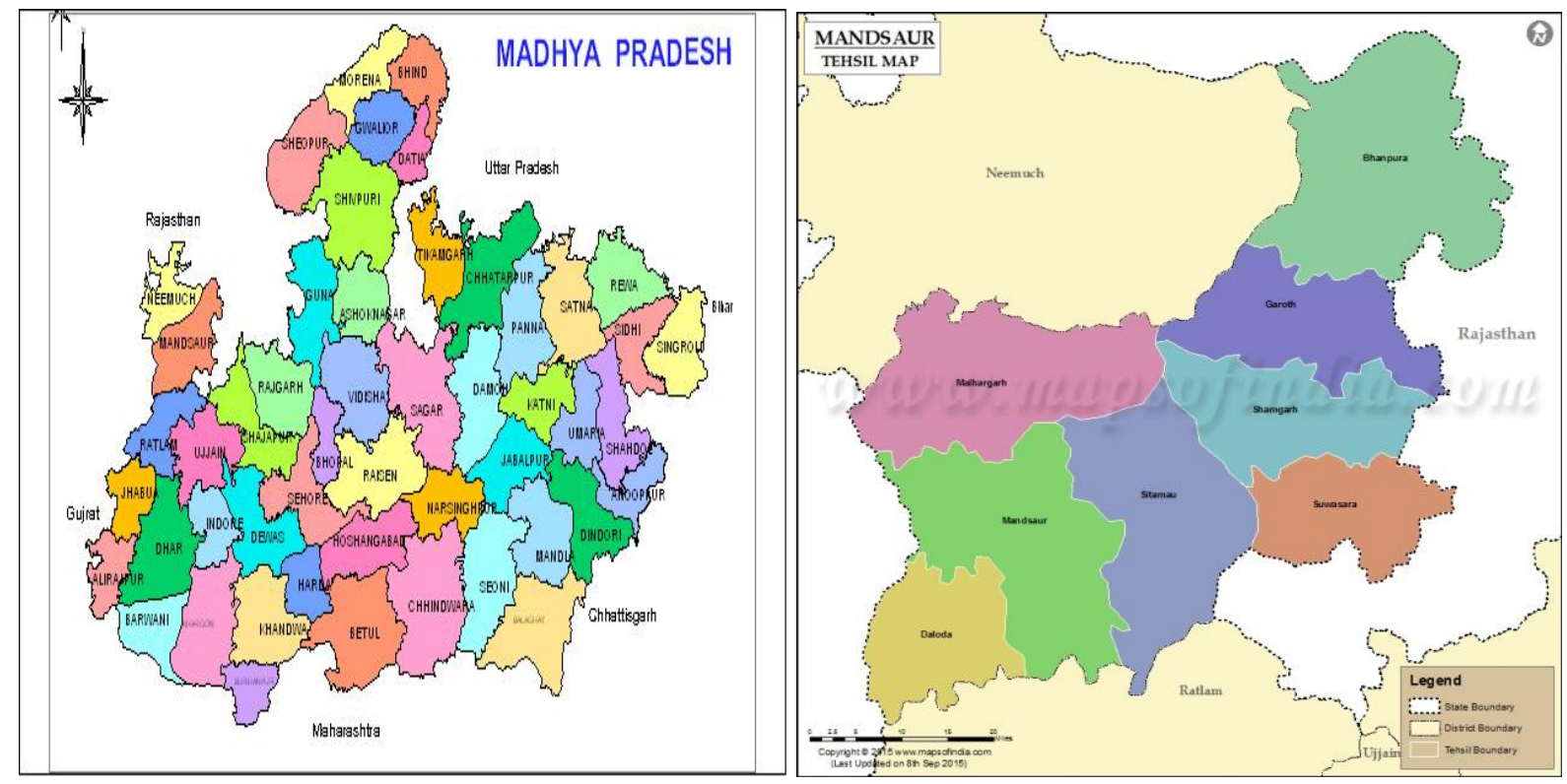

\section{Fig . 1: Relative density of weed species in opium poppy}

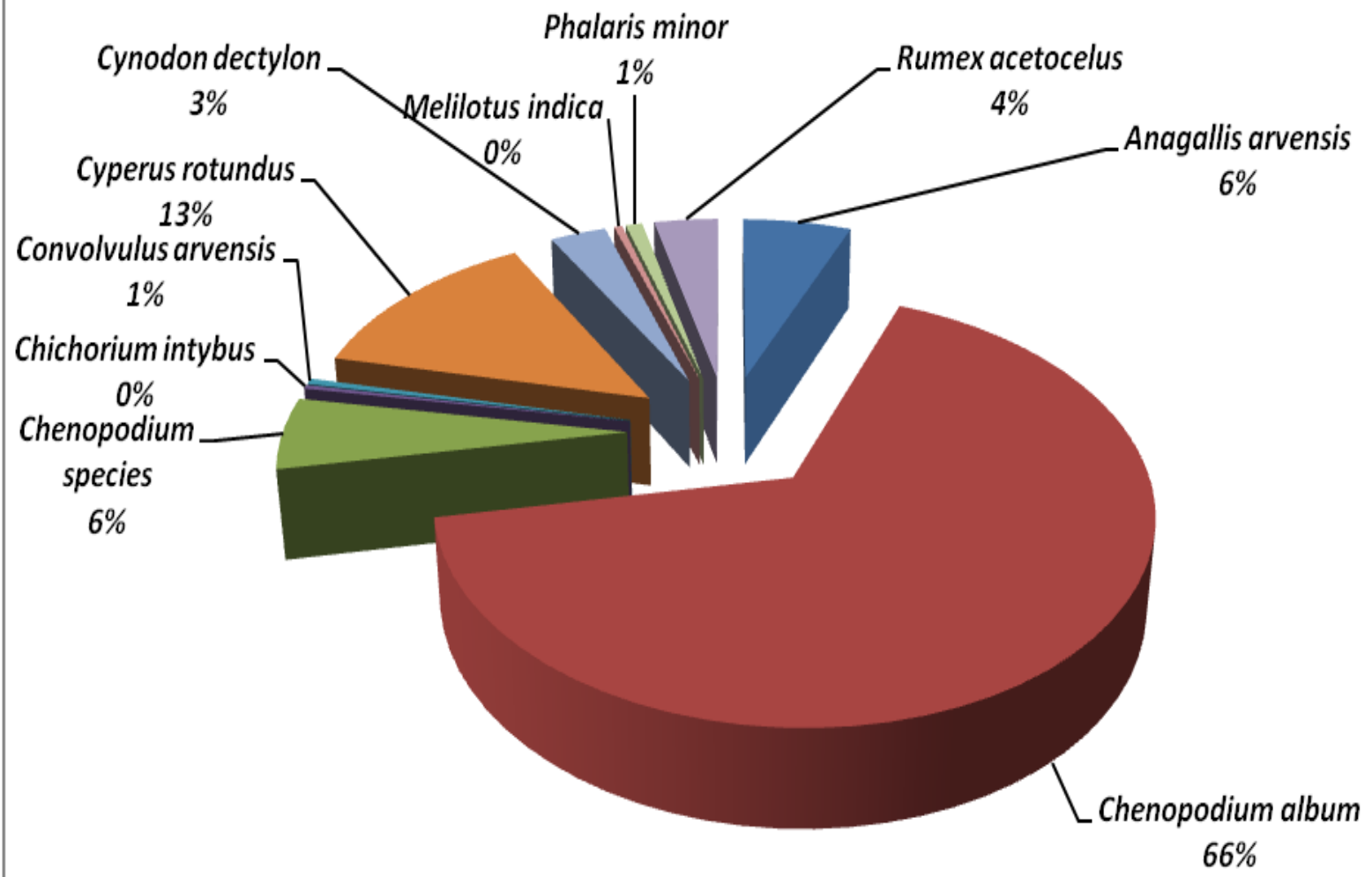


Table.1 Weed-flora of the experimental area

\begin{tabular}{|l|l|l|l|}
\hline Botanical Name & Common Name & Family & Hindi Name \\
\hline Anagallis arvensis L. & Red pimpernel & Primulaceae & Krishnaneel \\
\hline Chenopodium album L. & Lambsquarters & Chenopodiaceae & Chaulai \\
\hline Chichorium intybus L. & Chicory & Asteraceae & Kasni \\
\hline Convolvulus arvensis L. & Fieldbind weed & Convolvulaceae & Hirankhuri \\
\hline Cyperus rotundus. L. & Purple nutsedge & Cyperaceae & Motha \\
\hline Cynodon dectylon $($ L.) Pers & Bermuda grass & Poaceae & Doob \\
\hline Melilotus indica $(\mathbf{L}$.$) All.$ & Yellow sweet clover & Fabaceae & Peeli Senji \\
\hline Phalaris minor Retz. & Little seed canary grass & Poaceae & Gehu ka Mama, Gilli danda \\
\hline Rumex dentatus L. & Toothed dock & Polygonaceae & Jangali Palak \\
\hline
\end{tabular}

Table.2 Floristic composition of weed flora in opium poppy

\begin{tabular}{|c|c|c|c|c|c|c|}
\hline Weed Name & $\begin{array}{l}\text { Relative } \\
\text { Density } \\
(\%)\end{array}$ & $\begin{array}{l}\text { Relative } \\
\text { Frequency } \\
(\%)\end{array}$ & $\begin{array}{l}\text { Relative } \\
\text { Dominance } \\
(\%)\end{array}$ & $\begin{array}{l}\text { Importance } \\
\text { Value Index } \\
\text { (IVI) }\end{array}$ & $\begin{array}{l}\text { Importance Value } \\
\text { Percentage (IVP) }\end{array}$ & $\begin{array}{l}\text { Summed } \\
\text { Dominance } \\
\text { Ratio (SDR) }\end{array}$ \\
\hline Anagallis arvensis L. & 6.02 & 9.09 & 9.73 & 24.84 & 8.28 & 7.56 \\
\hline Chenopodium album $\mathbf{L}$. & 66.05 & 22.73 & 42.73 & 131.51 & 43.84 & 44.39 \\
\hline Chenopodium species & 5.71 & 18.18 & 4.62 & 28.51 & 9.50 & 11.95 \\
\hline Chichorium intybus $\mathrm{L}$. & 0.31 & 2.27 & 2.00 & 4.58 & 1.53 & 1.29 \\
\hline Convolvulus arvensis $\mathrm{L}$. & 0.46 & 2.27 & 2.99 & 5.72 & 1.91 & 1.37 \\
\hline Cyperus rotundus $\mathrm{L}$. & 13.43 & 20.45 & 9.66 & 43.54 & 14.51 & 16.94 \\
\hline Cynodon dectylon (L.) Pers & 3.09 & 2.27 & 19.97 & 25.33 & 8.44 & 2.68 \\
\hline Melilotus indica (L.) All. & 0.46 & 4.55 & 1.50 & 6.51 & 2.17 & 2.51 \\
\hline Phalaris minor Retz. & 0.93 & 4.55 & 2.99 & 8.47 & 2.82 & 2.74 \\
\hline Rumex dentatus $\mathbf{L}$. & 3.55 & 13.64 & 3.82 & 21.01 & 7.00 & 8.60 \\
\hline
\end{tabular}


The findings of present study suggest that Chenopodium album was the predominant weeds in opium poppy.

\section{References}

Das T.K. 2008. Weed Science. Basics and Application. New Delhi. Jain brothers. $901 \mathrm{p}$.

Frick B., Thomas AG. 1992. Weed survey in different tillage systems in South eastern Ontario field crops. Canadian Journal of Plant Science. 72, 13371347.

Korres N.E., Froud-Williams R.J. 2002. Effects of winter wheat cultivars and seed rate on the biological characteristics of naturally occurring weed flora. Weed Research. 42, 417428.

McCully K.V., Sampson M.G., Watson A.K. 1991. Weed survey of Nova Scotia, Lowbush blueberry (Vaccinium angustifolium) fields. Weed Science, 39, 180-185.

Thomas A.G. 1985. Weed survey system used in Saskatchewan for cereal and oilseeds crops. Weed Science. 33, 34-43.

Zimdahl R.L. 2007. Fundamentals of Weed Science. Third edition. Academic press. New York. 689.

\section{How to cite this article:}

Rajiv Dubey, R. P. Patel, Basant Katauli and Dharmendra Patidar. 2018. Floristic Composition of Weeds in Opium Poppy Grown Under Climatic Conditions of Malwa Plateau of Madhya Pradesh. Int.J.Curr.Microbiol.App.Sci. 7(02): 3749-3753.

doi: https://doi.org/10.20546/ijcmas.2018.702.443 